\title{
PERSEPSI SISWA TENTANG KOMPETENSI PEDAGOGIK DAN KOMPETENSI KEPRIBADIAN GURU
}

\author{
Nuryovi $^{1}$, Ono Wiharna ${ }^{2}$, Sriyono $^{3}$ \\ Universitas Pendidikan Indonesia \\ Jl. Dr. Setiabudhi No. 229 Bandung 40154 \\ nuryovi3@gmail.com
}

\begin{abstract}
ABSTRAK
Kompetensi tersebut meliputi kompetensi pedagogik dan kepribadian. Tujuan dari penelitian ini untuk menggambarkan persepsi siswa tentang kompetensi pedagogik dan kepribadian guru pada mata pelajaran Pekerjaan Dasar Teknik Otomotif (PDTO). Penelitian ini menggunakan metode deskriptif dengan pendekatan kuantitatif. Sampel penelitian terdiri dari siswa kelas X Program Keahlian Teknik Kendaraan Ringan SMK Negeri 1 Katapang yang berjumlah 100 orang. Teknik pengumpulan data penelelitian dengan menggunakan angket tertutup skala Likert. Berdasarkan hasil temuan dan pembahasan, persepsi siswa pada kedua kompetensi ini berada pada kriteria baik. Persepsi siswa tentang kompetensi pedagogik guru menunjukkan hasil penelitian dalam kriteria baik. Secara rinci, persepsi siswa tentang kompetensi pedagogik guru dibagi menjadi empat indikator yaitu: 1) wawasan kependidikan pada kriteria baik, 2) pengelolaan pembelajaran sebesar pada kriteria baik, 3) pemanfaatan pembelajaran pada kriteria baik, dan 4) pengembangan peserta didik pada kriteria cukup. Hasil temuan dan pembahasan penelitian persepsi siswa pada kompetensi kepribadian menunjukkan hasil pada kriteria baik. Kompetensi kepribadian penelitian dibagi menjadi empat indikator yaitu: 1) berakhlak mulia pada kriteria sangat baik, 2) mantap, stabil dan dewasa pada kriteria baik, 3) demokrasi, arif, bijaksana, dan berwibawa pada kriteria baik, dan 4) jujur dan sportif pada kriteria baik.
\end{abstract}

Kata kunci: persepsi, kompetensi pedagogik, kompetensi kepribadian

\section{PENDAHULUAN}

Pendidikan dan pengajaran merupakan sesuatu yang amat penting dalam membangun karakter anak bangsa. Kedudukan atau peran seorang guru merupakan faktor utama sebagai sarana dalam berhasilnya pendidikan dan pengajaran. Guru merupakan komponen untuk membina dan membimbing siswa agar sesuai dengan tujuan pendidikan. Mengingat peranan itu begitu penting, maka guru dituntut harus mempunyai kompetensi. Kompetensi guru itu meliputi: kinerja (performance), penguasaan landasan profesional/akademik, penguasaan materi akademik, penguasaan keterampilan/proses kerja, penguasaan penyesuain interaksional, dan kepribadian (Yusuf dan Sugandhi, 2011). Undang-undang Republik Indonesia Nomor 14 tahun 2005 tentang Guru dan Dosen (pasal 10 ayat 1) membahas mengenai kompetensi yang wajib dimiliki oleh guru meliputi kompetensi pedagogik, kompetensi kepribadian, kompetensi sosial, dan kompetensi profesional yang diperoleh melalui pendidikan profesi. Keempat kompetensi ini merupakan hal pokok yang harus dimiliki oleh seorang guru. Setiap kompetensi saling terkait dan saling

\footnotetext{
${ }^{1}$ Mahasiswa Departemen Pendidikan Teknik Mesin FPTK, UPI

2 Dosen Departemen Pendidikan Teknik Mesin FPTK, UPI

3 Dosen Departemen Pendidikan Teknik Mesin FPTK, UPI
} 
mempengaruhi. Guru sebagai pendidik sejati harus menguasai keempat kompetensi ini. Penguasaan kompetensi guru akan digambarkan secara nyata saat berinteraksi dengan siswa. Interaksi guru dengan siswa terjadi saat proses pembelajaran berlangsung (Danim, 2010).

Pendidikan yang baik akan terwujud bila proses dalam pembelajaran dilakukan dengan benar. Pendidik profesional merupakan jembatan untuk siswa mendapatkan ilmu saat pembelajaran (Payong, 2011). Siswa yang belajar dengan baik dapat memperoleh hasil yang baik dan merasa senang dalam belajar. Guru yang disenangi oleh siswa jauh lebih mudah dalam melakukan pembelajaran, karena siswa mempunyai persepsi yang baik pada gurunya. Persepsi merupakan suatu opini atau pandangan dari seseorang dalam melihat suatu objek atau informasi pada lingkungannya. Jika kita menyebutkan ikan, maka bayangan atau gambaran detail setiap orang pasti berbeda. Anggapan siswa mengenai cara mengajar guru, dapat pula dikatakan sebagai persepsi.

Persepsi adalah proses yang menyangkut masuknya pesan atau informasi ke dalam otak manusia. Melalui persepsi manusia terus menerus mengadakan hubungan dengan lingkungannya. Hubungan ini dilakukan lewat inderanya, yaitu indera penglihat, pendengar, peraba, perasa dan pencium (Slameto, 2010). Kompetensi guru dan persepsi siswa keduanya saling berkaitan. Pentingnya kompetensi guru yang dimiliki akan mempengaruhi persepsi siswa. Persepsi siswa akan baik jika guru menguasai kompetensikompetensi yang ada.

Melihat begitu pentingnya kompetensi guru dan persepsi siswa, peneliti dalam hal ini menemukan sebuah fakta di lapangan. Fakta di lapangan tentang kompetensi guru dalam persepsi siswa ditemukan pada saat peneliti melaksanakan Program Latihan Profesi (PLP). Kenyataannya pada proses pembelajaran mata pelajaran Pekerjaan Dasar Teknik otomotif (PDTO), terlihat sikap siswa yang berbeda. Kesenjangan itu diakibatkan adanya perbedaan persepsi pada diri siswa tentang gurunya. Sebagian siswa memiliki persepsi yang baik dan sebagian lainnya terlihat memiliki persepsi yang kurang baik.

Melihat lebih jauh kesenjangan itu, peneliti mulai berfikir dan menganalisis apa yang membuat para siswa ini mengalami perbedaan persepsi. Data awal penunjang untuk melihat kesenjangan yang dapat terlihat dari observasi awal yang dilakukan peneliti. Observasi atau suvei ini mengenai persepsi siswa tentang gurunya. Peneliti menanyakan secara lisan tentang seperti apa persepsi beberapa siswa tentang guru mata pelajaran PDTO. Isi dari percakapan hasil observasi awal yaitu: responden pertama mempersepsikan bahwa guru mata pelajaran PDTO kurang disiplin dalam kehadiran. Responden kedua 
mempersepsikan bahwa materi yang diajarkan belum tersampaikan, sehingga pada saat melakukan evaluasi pengajaran responden merasa kebingungan. Hasil observasi awal ini, menjadikan data empirik untuk penunjang penelitian yang akan dilakukan.

Tentunya faktor-faktor yang mempengaruhi persepsi siswa bervariasi. Bisa mencakup cara mengajar guru, model pembelajaran, materi pembelajaran, media pembelajaran, kepribadian guru, kedekatan guru dengan siswa, komunikasi antara guru dengan siswa, penguasaan materi, maupun fasilitas belajar di sekolah dan lain sebagainya. Beberapa faktor itu terkandung dalam empat kompetensi guru. Jika persepsi terhadap kompetensi pedagogik guru baik, maka motivasi belajarnya akan baik pula (Amin, Aunurrahman, dan Thamrin, 2013).

Penelitian ini terfokus pada kompetensi pedagogik dan kompetensi kepribadian guru. Persepsi siswa dalam penelitian ini, diperlukan untuk menggambarkan kompetensi guru. Hal itu dirasa perlu, melihat penelitan yang sebelumnya yang telah dilakukan menyimpulkan kompetensi pedagogik berperan penting dalam motivasi belajar. Oleh sebab itu, penelitian tentang kompetensi pedagogik dan kompetensi kepribadian guru dirasa perlu karena beberapa kompetensi ini merupakan kompetensi yang wajib dimiliki oleh setiap guru (Mulyasa, 2011).

Guru merupakan obyek utama yang selalu dilihat siswa dalam kelas, terutama saat pembelajaran. Guru merupakan fokus utama yang sangat penting bagi siswa untuk dapat belajar dengan baik. Pada akhirnya, siswa akan membentuk opini atau persepsi mengenai gurunya. Apabila persepsi siswa mengenai guru baik, maka proses pembelajaran akan baik. Sebaliknya, jika persepsi siswa tentang gurunya kurang baik, maka keinginan belajar siswa akan berkurang juga. Melihat dari hal tersebut, maka dapat dikatakan setiap siswa memiliki persepsi berbeda-beda tentang gurunya. Penelitian ini akan menggali lebih jauh gambaran persepsi siswa tentang kompetensi pedagogik dan kepribadian guru.

\section{METODE PENELITIAN}

Metode yang digunakan oleh peneliti dalam penelitan ini adalah metode deskriptif. Metode penelitian deskriptif digunakan oleh peneliti karena dianggap sesuai dengan permasalahan yang sedang diteliti. Peneliti menggunakan penelitian deskriptif karena sesuai tujuan dalam gambaran yang akan dilakukan dalam penelitian ini. Pendekatan penelitian yang digunakan oleh peneliti merupakan pendekatan kuantitatif. Pemilihan pendekatan ini berdasarkan karena pengolahan data penelitian survei dapat dilakukan dengan cara kuantitatif. Penelitian survei adalah prosedur dalam penelitian kuantitatif di 
mana penelitian mengadministrasikan survei pada suatu sampel atau pada seluruh populasi orang untuk mendeskripsikan sikap, pendapat, perilaku, atau ciri khusus populasi. Penelitian dengan pendekatan kuantitatif dipilih sebagaimana untuk mengolah data, sehingga hasil pengolahan data dapat dideskripsikan dalam hasil temuan dan pembahasan.

Teknik sampling yang peneliti pilih yaitu non probability sampling dengan teknik sampling jenuh. Pengambilan teknik ini, karena dalam penelitian ini populasinya dijadikan sampel. Sampel pada penelitian ini adalah siswa-siswa SMK Negeri 1 Katapang Program Keahlian Teknik Kendaraan Ringan Kelas X TKR 1, X TKR 2 dan X TKR 3. Latar belakang dari pengambilan sampel ini dirasa karena masih aktif di sekolah sehingga memudahkan pengambilan data. Penelitian ini sampel nya adalah 100 orang, sehingga akan menghasilkan data penelitian yang lebih akurat.

Instrumen yang peneliti pilih untuk penelitian ini adalah angket. Angket yang digunakan untuk mengukur persepsi siswa tentang kompetensi pedagogik dan kompetensi kepribadian guru adalah skala Likert. Agar angket yang digunakan dapat memberikan informasi detail yang dibutuhkan, dalam penelitian ini maka dibutuhkan proses pengujian instrumen. Pengujian instrumen dilakukan sebelum pengambilan data pada siswa. Pengujian yang akan dilakukan dengan cara di judgement oleh ahli.

\section{HASIL PENELITIAN}

Hasil penelitian diperoleh tentang persepsi siswa tentang kompetensi pedagogik dan kompetensi kepribadian guru mata pelajaran PDTO. Persepsi siswa tentang kompetensi pedagogik sebesar $69,27 \%$ dan kompetensi kepribadian 78,83\%. Hal ini menunjukkan bahwa persepsi siswa tentang dua kompetensi ini baik. Artinya guru mata pelajaran PDTO mempunyai kompetensi pedagogik dan kompetensi kepribadian pada kriteria baik, sehingga siswa mempersepsikan gurunya baik.

\section{PEMBAHASAN}

Penguasaan kompetensi pedagogik guru dalam pembelajaran sangat penting. Pentingnya penguasaan kompetensi ini untuk menunjang keberhasilan dalam proses pembelajaran (Fathorrahman, 2017). Hal ini menunjukkan bahwa pentingnya kompetensi guru dalam sistem pendidikan di Indonesia. Penelitian yang dilakukan membahas tentang kompetensi pedagogik guru mata pelajaran PDTO. Ada empat indikator kompetensi pedagogik yang diambil dalam penelitian ini. Indikator tersebut, antara lain: wawasan kependidikan, pengelolaan pembelajaran, pemanfaatan pembelajaran, dan pengembangan 
peserta didik. Keempat indikator ini menjadi acuan untuk melihat persepsi siswa tentang kompetensi pedagogik guru (Janawi, 2011). Hasil temuan dari penelitian ini menunjukkan bahwa persepsi siswa tentang kompetensi pedagogik dipaparkan setiap indikator. Tiga indikator yaitu wawasan kependidikan, Pengelolaan pembelajaran dan Pemanfaatan Pembelajaran menunjukkan rata-rata 70\% lebih. Artinya tiga indikator ini termasuk pada kriteria baik. Indikator pengembangan peserta didik hanya mendapatkan angka $57,70 \%$ yang berarti dalam kriteria cukup. Rata-rata dari keempat indikator pada kompetensi pedagogik ini menunjukkan persentase sebesar $69,27 \%$. Kriteria dari rata-rata keempat indikator ini termasuk dalam kategori baik.

Kepribadian guru adalah contoh bagi siswa-siswanya. Guru merupakan sosok yang harus terlihat sempurna agar menjadi contoh yang baik. Sama hal nya dengan kompetensi pedagogik, kompetensi kepribadian guru merupakan hal yang wajib dimiliki oleh guru. Kompetensi kepribadian merupakan kompetensi yang dapat membentuk sikap dan mendidik siswa untuk menjadi manusia yang baik. Pentingnya kompetensi kepribadian guru yang harus dimiliki, karena guru merupakan objek yang sering dilihat oleh siswa. Penglihatan siswa tentang gurunya dapat tercermin dalam persepsi yang baik atau kurang baik.

Kompetensi kepribadian guru diteliti untuk melihat gambaran dari persepsi siswa tentang gurunya. Baik atau kurang baiknya kompetensi kepribadian guru dapat tergambar dari hasil penelitian ini. Kompetensi kepribadian guru dibagi menjadi beberapa indikator. Ada empat pembagian indikator dalam pengambilan data pada kompetensi kepribadian. Indikator pertama yaitu berakhlak mulia, kedua: mantap, stabil dan dewasa, ketiga: demokrasi, arif, bijaksana, dan berwibawa, dan indikator yang keempat adalah jujur dan sportif. Pengolahan data dilakukan untuk melihat temuan atau hasil penelitian yang dilakukan. Hasil dari penelitian persepsi siswa tentang kompetensi kepribadian ini, digambarkan pada indikator-indikator.

Nilai persentasi persepsi siswa tentang kompetensi kepribadian guru lebih besar dari pada kompetensi pedagogik. Tiga indikator yaitu, pertama (mantap, stabil dan dewasa), kedua (demokrasi, arif, bijaksana, dan berwibawa) dan ketiga (jujur dan sportif) menunjukkan rata-rata pada nilai persentase $70 \%$ lebih. Hal ini menggambarkan bahwa tiga indikator ini termasuk dalam kriteria baik. Satu indikator lagi yaitu, berakhlak mulia menunjukkan nilai persentase $86,17 \%$ termasuk pada kriteria sangat baik.

Peningkatan kompetensi guru akan mempengaruhi dalam proses belajar. Guru profesional akan dapat menyelenggarakan proses pembelajaran dan penilaian-penilaian 
yang menyenangkan bagi guru, sehingga dapat mendorong tumbuhnya kreativitas belajar pada diri siswa (Fathurrohman dan Suryana, 2012). Artinya bahwa, guru profesional merupakan guru yang memenuhi kompetensinya.

\section{KESIMPULAN}

Kesimpulan penelitian, yaitu: persepsi siswa tentang kompetensi pedagogik guru pada penelitian yang dilakukan menunjukkan hasil dalam kriteria baik. Artinya bahwa, persepsi siswa tentang guru mata pelajaran PDTO baik. Persepsi siswa tentang kompetensi kepribadian guru. Hasil temuan dan pembahasan penelitian persepsi siswa pada kompetensi kepribadian ini menunjukkan pada kriteria baik.

\section{REFERENSI}

Amin, M., Aunurrahman, dan Thamrin, M. (2013). Hubungan Kompetensi Pedagogik dan Kompetensi Kepribadian dengan Kinerja Guru. Jurnal Pendidikan dan Pembelajaran 2(7).

Danim, S. (2010). Profesionalisme dan Etika Profesi Guru. Bandung: Alfabeta

Fathorrahman. (2017). Kompetensi Pedagogik, Profesional, Kepribadian dan Kompetensi Sosial Dosen. Akademika. 15(1) hal. 1-6.

Fathurrohman, P dan Suryana, A. (2012). Guru Profesional. Bandung: Refika Aditama.

Janawi. (2011). Kompetensi Guru: Citra Guru Profesional. Bandung: Alfabeta.

Mulyasa, E. (2011). Standar Kompetensi dan Sertifikasi Guru. Cet. ke-5. Bandung: Remaja Rosdakarya.

Payong, M.R. (2011). Sertifikasi Profesi Guru: Konsep Dasar, Problematika, dan Implementasinya. Jakarta: Indeks.

Slameto. (2010). Belajar dan Faktor-faktor yang Mempengaruhinya. Jakarta: Rineka Cipta.

Yusuf, L.N S. dan Sugandhi, N. M. (2011). Perkembanagn Peserta Didik. Jakarta: Rajagrafindo Persada. 